\title{
Variation in a host-epiphyte relationship along a wave exposure gradient*
}

\author{
Phillip S. Levin ${ }^{1}$, A. C. Mathieson ${ }^{2}$ \\ ${ }^{1}$ Department of Zoology, and ${ }^{2}$ Department of Plant Biology and the Jackson Esfuarine Laboratory, \\ University of New Hampshire, Durham, New Hampshire 03824, USA
}

\begin{abstract}
The red alga Polysiphonia lanosa (L.). Tandy is an obligate epiphyte that primarily occurs on the fucoid brown algal basiphyte Ascophyllum nodosum (L.) Le Jolis. In the present study we examine how epiphytic interactions between $P$. lanosa and $A$. nodosum vary along a wave exposure gradient within the southern Gulf of Maine, USA. P. lanosa was most dense on protected shores; however, because the stature of $P$. lanosa was greater on exposed than on sheltered shores, greater biomass occurred in exposed habitats. Epiphytic $P$. lanosa primarily attached to injured vegetative tissue at exposed sites, while its occurrence was primarily receptacular at sheltered sites. A significantly stronger correlation was found between host receptacle abundance and epiphyte abundance at a protected low than an exposed site. As a result, the distribution of epiphytes along the host's stipe varies at different sites. We suggest that changes in the distribution and abundance of $P$. lanosa across this wave exposure gradient are highly influenced by variations in the distribution and persistence of suitable attachment sites on the host plant. Because both the quantity and quality of attachment sites varies with exposure, we hypothesize that different processes limit or determine $P$. ianosa populations in different locations. In protected sites $P$. lanosa may be limited by the presence of adequate substrata (injured tissue and lateral pits) where successful recruitment may occur. By contrast, at exposed sites the supply of $P$. lanosa sporelings, rather than quantity of appropriate substrata, may limit population size.
\end{abstract}

\section{INTRODUCTION}

The processes that limit or modify abundances of individuals in populations on rocky shores have received considerable attention. Most of this work has focused on sessile invertebrates, while considerably fewer studies have examined the population ecology of intertidal seaweeds, particularly algal epiphytes.

Epiphytes are ubiquitous and important components of marine communities (Orth \& Montfrans 1984, Arrontes 1990), especially when primary substratum is limiting (Hay 1981a, b). The presence of epiphytes on marine macrophytes may result in a variety of complex interactions between hosts and epiphytes; as a result, the ecology of epiphytes is fundamentally different from that of algae attached to primary substratum (Hayward 1980, Orth \& Montfrans 1984). Such interactions may begin with non-random patterns of settle-

\footnotetext{
- Scientific contribution no. 1721 from the New Hampshire Agricultural Experiment Station; also issued as contribution no. 231 from the Jackson Estuarine Laboratory
}

ment and recruitment (Gonzales \& Goff 1989, Pearson \& Evans 1989, 1990). Host specificity by several epiphytic algal species is a dramatic example of nonrandom settlement and recruitment (Ducker \& Knox 1984). Additionally, post-recruitment survivorship of epiphytes may be related to the host, as epiphytes may experience reduced herbivore pressure when associated with a chemically defended host (Hay 1986).

Basiphytes or epiphyte hosts (sensu Ducker \& Knox 1984) exhibit a variety of defensive strategies to reduce epiphytism. Such strategies include the abscission or sloughing of outer cell walls ('skin') in fucoid and coralline algae (Filion-Myklebust \& Norton 1981, Johansen 1981, Moss 1982, Steneck 1982, Russell \& Veltcamp 1984). Additionally, the release of phenolic compounds (Zapata \& McMillan 1979, Moss 1982, Harlin 1987) and ephemeral life histories (den Hartog 1972) have been suggested as defenses from epiphytism.

Numerous investigators have studied patterns of species richness within epibiotic assemblages (Markham 1969, Ballantine 1979, Whittick 1983, Grahame \& Hanna 1989, Arrontes 1990, Rodriguez \& Stoner 1990). The composition of these assemblages varies both seasonally 
and spatially on macrophyte host tissues (Markham 1969, Whittick 1983, Arrontes 1990). Epiphytism is often greatest on old or injured sections of basiphytes (Ballantine 1979, Lobban \& Baxter 1983, Ducker \& Knox 1984. Pearson \& Evans 1989, 1990, Arrontes 1990). Physical factors, particularly desiccation and wave action, may also determine the species composition of epiphyte guilds (Hayward 1980, Grahame \& Hanna 1989).

Despite substantial work on marine epiphytes, their population ecology has received little attention (Harlin 1987). Of the numerous selective forces affecting epiphyte growth, the distribution and stability of suitable substrata is critically important (Benzing 1987). Although it is well known that the density, stature. longevity and dispersion of potential basiphytes varies with wave exposure (Lewis 1964, Lubchenco 1980, Cousens 1985, Mathieson \& Hehre 1986), the effects of such demographic patterns on epiphyte ecology have rarely been investigated (Harlin 1987)

The red alga Polysiphonia lanosa is an obligate epiphyte (Taylor 1957, Turner \& Evans 1977) that primarily occurs on the fucoid brown alga Ascophyllum nodosum. The rhizoids of $P$. lanosa penetrate the host and obtain some nutrition from $A$. nodosum (Rawlence \& Taylor 1970, Turner \& Evans 1977). However, the quantity of carbon obtained by P. lanosa is minimal (Harlin \& Craigie $1975)$ and $P$. lanosa is pigmented and capable of photosynthesis (Bidwell 1958. Fralick \& Mathieson 1975).

In the present study we examine the spatial variation of epiphytic interactions between Polysiphonia lanosa and Ascophyllum nodosum at several rocky intertidal habitats in the Northwest Atlantic. Field observations suggest that the distribution and abundance of $P$. lanosa are highly dependent upon the occurrence of injured host tissue and/or number of lateral shoots (Lobban \& Baxter 1983, Burke 1986, Pearson \& Evans 1989, 1990). Both of these morphological features of A. nodosum appear to be maximal in locales exposed to moderate wave action (Cousens 1985). In this paper we seek to extend previous studies on the population ecology of epiphytes by attempting to answer the following 3 questions: (1) Does the abundance and/or biomass of $P$. lanosa vary with wave exposure? (2) Does $P$ lanosa exhibit site-specific attachment to $A$. nodosum under varying wave exposure? (3) Is there any relationship between epiphyte abundance and the reproductive capacity of $A$. nodosum? If so, does this relationship change with varying wave exposure?

\section{METHODS}

The study was conducted at 3 sites: the sheltered (northwestern) and semi-exposed (eastern) shorelines of Jaffrey Point. Newcastle, New Hampshire and the exposed easternmost shoreline of Smuttynose Island, Maine, USA. The eastern shoreline of Jaffrey Point consists of large granitic outcrops on a semi-exposed shore, while the northwestern shoreline is protected from direct wave action from all directions (Mathieson et al. 1981). Smuttynose Island is the easternmost island of the Isles of Shoals archipelago, with the eastern shoreline being exposed to extreme wave action, particularly during storms (Sideman \& Mathieson 1983. Mathieson \& Penniman 1986). The 3 sites were selected to represent a gradient in wave exposure, with Smuttynose Island being the most exposed, the northwestern shoreline of Newcastle Island being the most protected, and the easternmost shoreline of Jaffery Point being intermediate. Previous work has characterized this exposure gradient, and detailed descriptions of these sites have been published elsewhere (Mathieson et al. 1981, Mathieson \& Hehre 1986, Mathieson \& Penniman 1986).

During February and March 1989, 50 Ascophyllum nodosum fronds were haphazardly collected at the upper and lowermost boundaries of the mid-intertidal zone of each site. The lower mid-intertidal zone was sampled because it is the location of highest Polysiphonia lanosa density (Burke 1986), while the upper mid-intertidal boundary was used for comparative evaluations. After being collected the samples were brought to the laboratory for an assessment of the number, weight and vertical stratification patterns of $P$. lanosa on host plants, as well as the occurrence of $A$. nodosum receptacles. Initially each $A$. nodosum frond was weighed (damp-dried) and measured (length from holdfast to apical tip). After the epiphytes were removed, the fronds were reweighed. An individual $P$. lanosa plant was designated as an individual sporeling or a clump having a discrete (single) attachment point. Ultimately the number and weight of $P$. lanosa plants per $A$. nodosum frond were enumerated for each site. To assess vertical stratification patterns of $P$. lanosa on $A$. nodosum fronds, the numbers of $P$. lanosa within $10 \mathrm{~cm}$ intervals along the frond were enumerated. The occurrence of injury sites on $A$. nodosum was also enumerated while quantifying the presence of $P$. lanosa. A variety of injury sites were apparent, including the loss of apical meristematic tissue, as well as various lesions, cuts and breakages on the intercalary surfaces and edges of $A$. nodosum.

Differences among sites for the various parameters evaluated were assessed using analysis of variance (ANOVA). An analysis of covariance was also used to test for differences of regression line slopes (Zar 1984). Prior to the analyses, data were tested for heterscedasticity, using Cochran's test (Underwood 1981). If variances were heterogeneous $(<0.05$ for Cochran's test), analyses were performed on transformed data. Counts 
were changed to $\log (x \pm 1)$ values and proportions were arcsine transformed (Underwood 1981).

\section{RESULTS}

Conspicuous differences in the abundance of Polysiphonia lanosa on vegetative tissue were evident among the study sites (Figs. $1 \& 2 ; F_{5,144}=4.29, \mathrm{p}=$ $0.001)$. The mean number of $P$. lanosa clumps per Ascophyllum nodosum frond on vegetative tissues at the protected low site was 38.2, which was ca 2 times greater than at any other site. Such differences were statistically significant (Tukey's HSD, p < 0.01). As the stature of epiphytes from the protected low site was much smaller than at the exposed sites, conspicuous

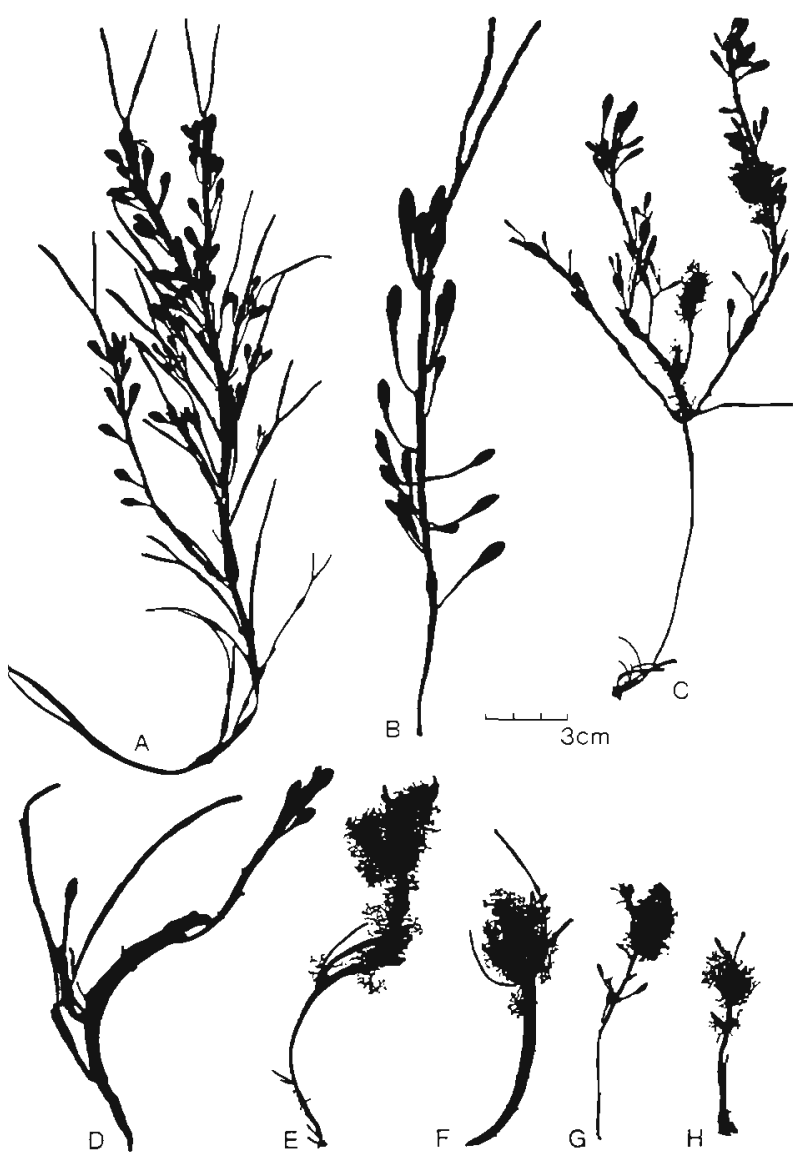

Fig. 1. Ascophyllum nodosum. Silhouettes of attached plants from 3 study sites, 2 at Jaffery Point, New Hampshire (A \& B = sheltered, $\dot{C}=$ semi-exposed) and one from the exposed site of Smuttynose Island, Maine (D to H). Note the elongated, reproductive fronds of $A$. nodosum without (A \& B) and with (C) visible epiphytic Polysiphonia lanosa. A reduction in stature of A. nodosum and increased biomass of epiphytes are evident at Smuttynose Island versus Jaffery Point (D to $\mathrm{H}$ )

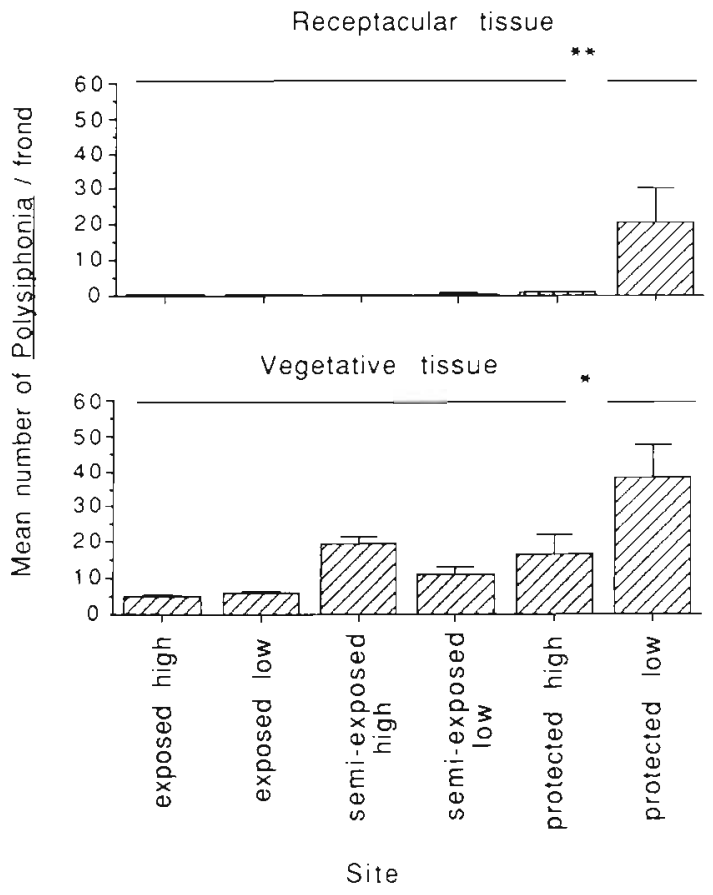

Fig. 2. Polysiphonia lanosa. Mean number on vegetative and receptacular tissues of Ascophyllum nodosum at 6 study sites. Horizontal bars join means which were not significantly different ( $p>0.05$ ) by Tukey's HSD tests. "Significant at $p<0.05$;

- significant at $p<0.01$ Error bars are $1 \mathrm{SE}$

differences of $P$. lanosa biomass on vegetative tissue were evident $\left(F_{5,144}=5.06, \mathrm{p}<0.001\right)$. Thus, the mean biomass at the exposed high and low sites were at least an order of magnitude greater than at any of the other sites (Fig. 3). Such patterns were still evident even when the data were standardized by dividing $P$. lanosa biomass by $A$. nodosum biomass.

Significant differences in the mean number of Polysiphonia lanosa clumps on receptacular tissue were also evident (Fig. 2, $F_{5,144}=4.26, \mathrm{p}=0.001$ ). For example, at the protected low site the number of receptacular epiphytes was at least 18 times greater than at the other 5 sites. As Ascophyllum nodosum sheds its receptacles precipitously each spring (Mathieson 1989), all of the receptacular epiphytes must be from the same cohort. When we accounted for differences in frond size among sites by dividing $P$. lanosa biomass by $A$. nodosum biomass, no differences in mean biomass of receptacular attached $P$. lanosa/ $A$. nodosum were evident among any sites $\left(F_{5,144}=1.47, \mathrm{p}=0.20\right)$.

Conspicuous differences in the location of Polysiphonia lanosa clumps on Ascophyllum nodosum fronds were found among exposed and protected sites (Fig. 4). The mean proportion of receptacular epiphytes varied significantly among sites $\left(F_{3,116}=18.12, \mathrm{p}<\right.$ 0.001 ), with the protected low site having the highest value (Tukey's HSD, $p<0.01$ ). Furthermore the pro- 
Receptacular tissue

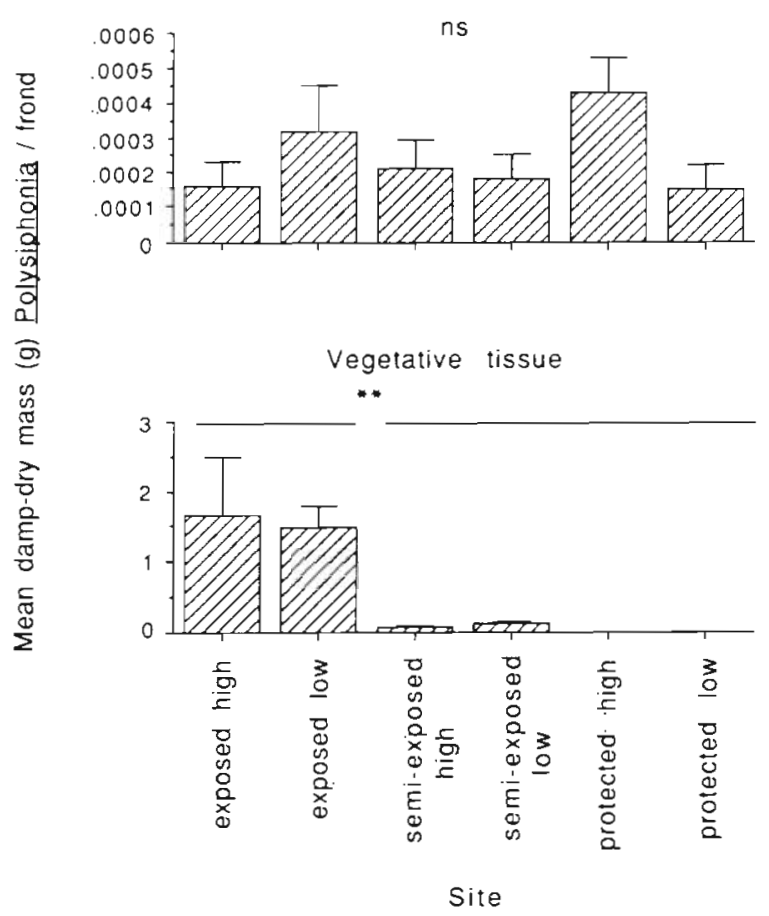

Fig. 3. Polysiphonia lanosa. Mean damp-dried weight of plants on receptacular and vegetative tissues of Ascophyllum nodosum at 6 study sites. Horizontal bars join means which were not significantly different $(p>0.05)$ by Tukey's HSD tests. - Significant at $p<0.01$. Error bars are 1 SE

tected high site had a significantly higher proportion of receptacular epiphytes than the exposed high site (Tukey's HSD, p < 0.05).

Injured Ascophyllum nodosum tissue had significantly higher numbers of Polysiphonia lanosa clumps than uninjured material (Fig. $4 ; F_{3.116}=11.59, \mathrm{p}<$ 0.001). Plants from exposed sites had a significantly higher proportion of epiphytes attached to injured tissue than those from protected sites (Tukey's HSD, p < 0.01 ). The mean proportions of epiphytes attached to injured tissue at the exposed high and low sites were 0.58 and 0.57 , respectively, while at the protected high and low sites the mean values were 0.19 and 0.019 , respectively.

The proportion of Polysiphonia lanosa attached to uninjured vegetative tissues was not significantly different among sites (Fig. $4 ; F_{3,116}=2.15, \mathrm{p}=0.1$ ). However, the mean proportion of uninjured attachment locations was more than twice that of injured tissues at the protected sites and nearly half the value of injured tissues at the exposed sites. Such results suggest that uninjured vegetative tissues are relatively more important attachment points at protected sites than at the exposed sites.
An analysis of covariance revealed significant differences among sites in the relationship between numbers of Polysiphonia lanosa clumps and numbers of Ascophyllum nodosum receptacles (Table 1). The slope of the regression line at the protected low site was significantly greater than at all other sites (Tukey's HSD, $p<0.001$; Fig. 5), indicating that a stronger relationship existed between receptacular number and the abundance of $P$. lanosa at this site than at the other 5 sites. In addition, the amount of variance in $P$. lanosa abundance explained by receptacular abundance varied among sites (Fig. 5). While $84.1 \%$ of the variation in epiphyte abundance was explained by receptacular abundance at the protected low site less than $37 \%$ was explained at the other 5 sites.

The distribution of clumps of Polysiphonia lanosa was not uniform along Ascophyllum nodosum fronds

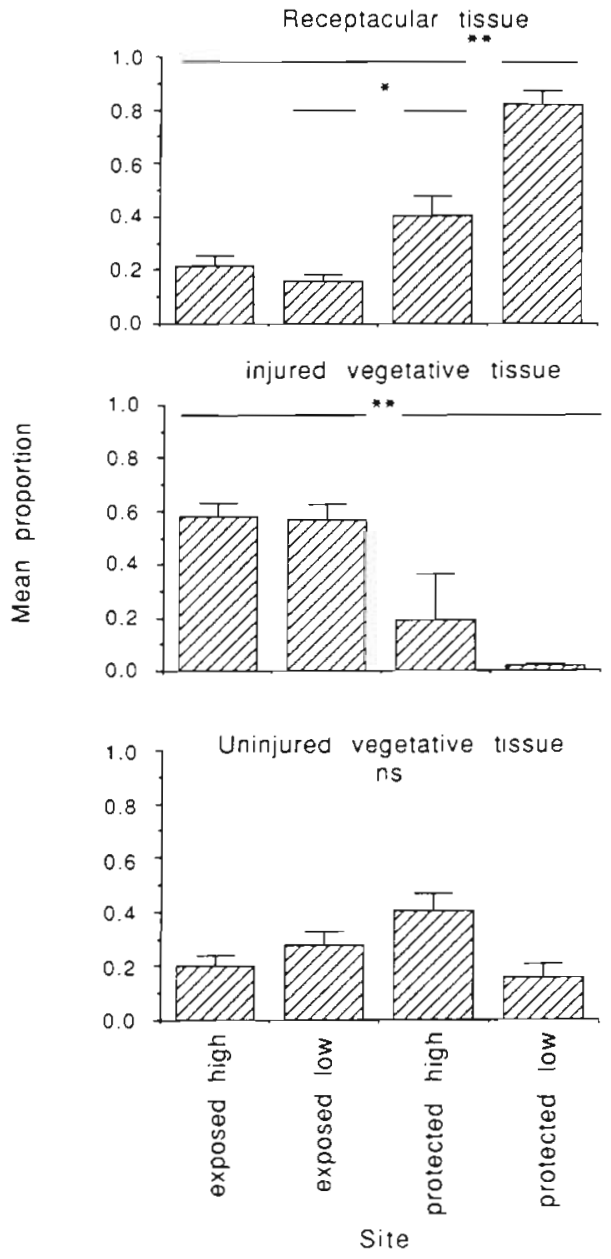

Fig. 4. Polysiphonia lanosa. Mean proportion of plants attached to receptacular and vegetative tissues (injured and healthy) at 4 study sites. Horizontal bars join means which were not significantly different $(p>0.05)$ by Tukey's HSD tests. 'Significant at $p<0.05 ; \cdots$ significant at $p<0.01$. Error bars are $1 \mathrm{SE}$ 
Table 1. Polysiphonia lanosa. Results of an analysis of covariance on the effects of site and receptacle number on abundance. The significant interaction term indicates that the relationship of $P$. lanosa and receptacle abundance varies among sites

\begin{tabular}{|c|c|c|c|c|c|}
\hline Source of variation & Sum of squares & $\mathrm{df}$ & Mean square & $F$ & $\mathrm{p}$ \\
\hline Site & 32.21 & 5 & 6.64 & 11.24 & $<0.001$ \\
\hline Receptacle number & 87.66 & 1 & 87.66 & 148.35 & $<0.001$ \\
\hline Site $\times$ Receptacle number & 32.457 & 5 & 6.491 & 10.99 & $<0.001$ \\
\hline Error & 170.167 & 288 & 0.591 & & \\
\hline
\end{tabular}

(Kolmogorov-Smirnov 1-sample test, $\mathrm{p}<0.001 ;$ e.g. Fig. 6). At the protected low site, the non-uniform distribution of epiphytes may result from the strong relationship between the abundances of receptacles and epiphytes which could produce a high correlation between the distribution of epiphytes and receptacles. However, this high correlation should not exist at the other 5 sites. Fig. 6 presents an initial assessment of these predictions using the protected low and exposed low sites. These 2 sites represent extremes along the wave exposure gradient we examined and provide an excellent contrast to test our hypothesis. Epiphyte distribution appears to be correlated with receptacular distribution at the protected low site, with maximal numbers near the frond's mid-length. In contrast, at the exposed site most $P$. lanosa was found near $A$. nodosum's holdfast, while its receptacles were most abundant at the mid-frond length.

\section{DISCUSSION}

Epiphyte populations are highly dependent upon the distribution and abundance of suitable substrata (Benzing 1987). Polysiphonia lanosa generally requires injured host tissues or lateral pits (i.e. sites of actual or potential branching) in order to successfully recruit onto host plants (Lobban \& Baxter 1983, Burke 1986, Pearson \& Evans 1989, 1990). In controlled laboratory experiments, Pearson \& Evans (1990) found that higher numbers of spores settled on the thallus and lateral pits of Ascophyllum nodosum fronds than onto vesicles. On the other hand, survivorship of in situ sporelings was highest in lateral pits and wound sites. Cousens $(1985,1986)$ demonstrated that these morphological features of $A$. nodosum fronds vary with wave exposure. In very sheltered coastal habitats, the number of injury sites (i.e. wounded tissue) on A. nodosum fronds is low. Addition-
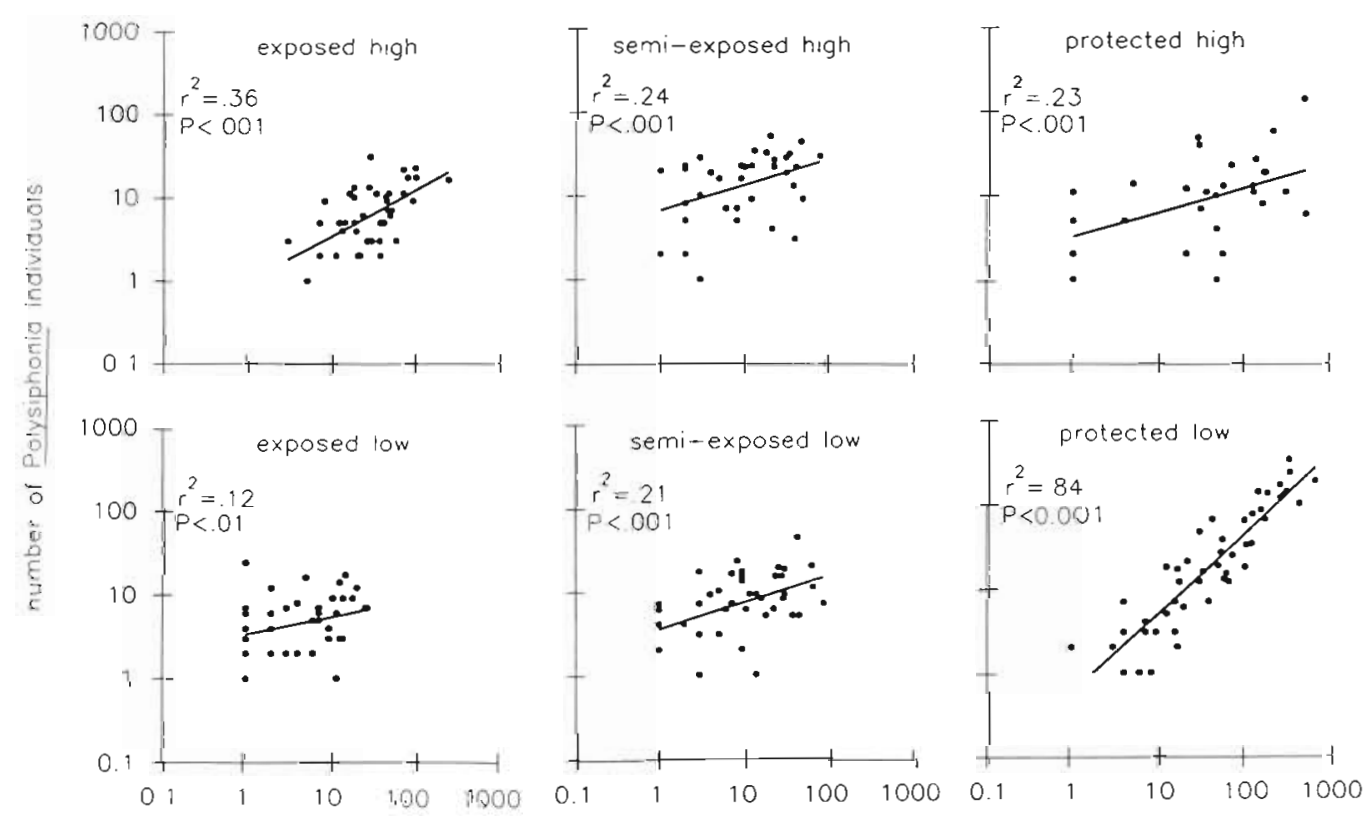

number of Ascophyllum receptocles

Fig. 5. Relationship between Polysiphonia lanosa and receptacular abundance at 6 study sites. The slopes of these regression lines are not equal (see Table 1), with the protected low site having a significantly greater slope than the other 5 sites 


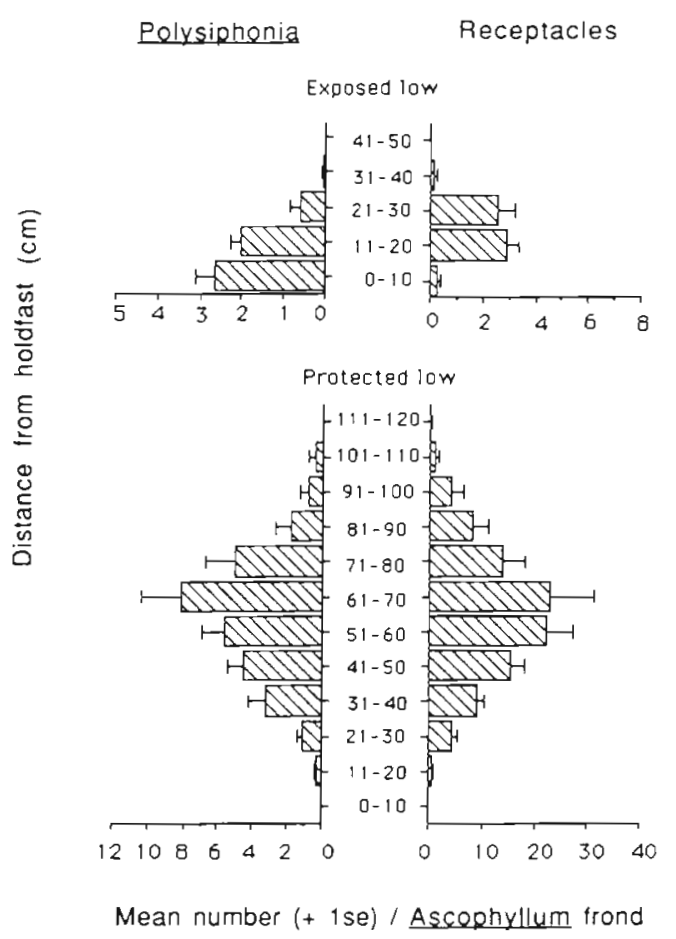

Fig. 6. An initial assessment of the hypothesis that Polysiphonia lanosa distribution is correlated with receptacular distribution at a protected site, but not at an exposed site. Error bars represent $1 \mathrm{SE}$

ally, the numbers of vegetative and reproductive laterals are reduced, and a truncation of the primary apex results in higher initiation of laterals than in sheltered locales (Cousens 1985). A. nodosum also exhibits its highest reproductive effort (i.e. receptacle mass/net annual production) in more exposed habitats (Cousens 1986).

The above-described changes in the morphology of Ascophyllum nodosum influence both the distribution and abundance of its epiphytes. Thus, we found much greater numbers of small Polysiphonia lanosa at the protected low site than at the other more exposed locations; however, these sporelings were primarily attached to receptacles. The lack of wounded tissue and vegetative laterals at such a protected low site suggests that reproductive laterais become the primary attachment point for settling germlings. During April and May when $A$. nodosum dehisces its receptacles (Mathieson et al. 1976, Mathieson 1989) most of the biomass of $P$. lanosa biomass would be lost at this site. By contrast, at exposed sites epiphytes are primarily attached to injured vegetative tissues. Thus, the spring dehiscence of $A$. nodosum receptacles in exposed sites would not result in as significant a loss of epiphyte biomass as at protected sites.

The factors that limit or induce change in marine populations have been a matter of much debate (see reviews by Underwood \& Denley 1984 and Doherty \&
Williams 1988). While we did not directly investigate the regulation or limitation of Polysiphonia lanosa populations our data suggest that this host-epiphyte system may be ideal for experimental manipulations investigating factors important to the structure of marine populations. Because the morphology of Ascophylium nodosum changes dramatically between different habitats, different processes may limit or induce spatial variation in $P$. lanosa population size in different sites. Thus, we propose the following hypothesis. In sheltered coastal sites, populations of $P$. lanosa are limited by the number of locations where successful recruitment may occur (i.e. wounded tissue and lateral pits). Such a hypothesis suggests that sporelings are plentiful and that intraspecific competition for wound sites or lateral pits results in densitydependent rates of recruitment to mature populations. Therefore, in the absence of disturbance, $P$, lanosa (or other similar epiphytes) would saturate the available permanent habitats. Excess sporelings would be forced to colonize receptacles and would subsequently be lost before entering the adult population.

In exposed locations, Ascophyllum noclosum fronds may be undersaturated with sporelings relative to the number of available wound sites and lateral pits. Such patterns would indicate that populations of Polysiphonia lanosa are recruitment limited (sensu Doherty 1981, Victor 1983) or recruitment determined (sensu Forrester 1990). If populations of $P$. lanosa are recruitment limited then the abundance of sporelings would set the upper boundary of population size. Similarly, if these populations are recruitment determined then differential availability of sporelings in space and time would be reflected in subsequent spatial and temporal variations of adult populations. In either case it is the supply of sporelings, not the amount of suitable substrata, which would be the critical factor to the dynamics of the epiphyte population.

Some brown algal epiphytes (e.g. Elachista fucicola) also exhibit differential abundances on fucoid receptacular tissue depending on habitat. Russell (1988), for example, found that E. fucicola occurred on receptacles of Fucus vesiculosus more frequently on protected versus exposed shores. In exposed sites E. fucicola was more common on stipes than on receptacles. As in the hostepiphyte association we described, the annual shedding of receptacles will result in an substantial loss of epiphytes in protected sites, but less so at exposed sites (Russell 1988). Consequently, the hypothesis that different processes limit $P$. lanosa populations in varying habitats may be generalizable to other epiphyte populations.

Other biotic factors may also contribute to these complex patterns of epiphyte distribution and abundance. Mesograzers (small herbivorous invertebrates) are important members of intertidal communities (Lub- 
chenco 1978, 1980, Lubchenco \& Gaines 1981, Mathieson et al, 1991). Mesograzers may directly consume epiphytes, and they may indirectly influence epiphyte distribution by creating patterns of injury. Several studies have recently implicated amphipods as important mesograzers in host-epiphyte relationships (Zimmerman et al. 1979, Brawley \& Adey 1981, Norton \& Benson 1983, D'Antonio 1985, Buschmann \& Santelices 1987, Duffy 1990). One of the most abundant algal-dwelling amphipods in the Northwest Atlantic is Hyale nilssoni, which readily consumes both Polysiphonia lanosa and Ascophyllum nodosum (McBane \& Croker 1983). Hence, it may play a role in this hostepiphyte relationship by directly consuming $P$. lanosa or by injuring $A$. nodosum.

The most abundant and important mesograzer on New England rocky shores is the gastropod Littorina littorea (Lubchenco 1978). Polysiphonia lanosa is consumed by $L$. littorea (Lubchenco 1978), and we have often observed this gastropod, as well as Littorina obtusata, grazing on P. lanosa at Jaffery Point. Additionally, grazing by $L$. littorea or $L$. obtusata on Ascophyllum nodosum or its epibiota may result in tissue injury, influencing the number and/or location of attachment sites available to $P$. lanosa spores.

All populations of Ascophyllum nodosum investigated to date harbor the ascomycete fungus $M y c 0-$ sphaerella ascophylli (Kohlmeyer \& Kohlmeyer 1972). Garbary \& Gautam (1989) found a strong correlation between the biomass of Polysiphonia lanosa and perithecial density of $M$. ascophylli. Their study also showed that receptacles of $A$. nodosum had the highest density of fungal hyphae. One might speculate that the presence of the fungus could provide a cue for the attachment of $P$. lanosa sporelings (but cf. Pearson \& Evans 1990). Future work enumerating how M. ascophylli perithecial density changes with wave exposure as well as experimental manipulations of fungal densities would be of interest.

Most earlier studies of host-epiphyte interactions have been conducted primarily at single sites (e.g. Markham 1969, Lobban \& Baxter 1983, Garbary \& Gautam 1989, Grahame \& Hanna 1989, Pearson \& Evans 1990). The present study demonstrates that the nature of host-epiphyte interactions changes with wave exposure. We believe that comparative investigations among sites or habitats are necessary to illuminate the complex nature of these interrelationships.

Acknowledgements. We thank G. E. Forrester, M. Ganger, T. P. Good, W. Lambert, T. Lee, M. E. Hay, R. R. Olson and P. $F$. Sale and 2 anonymous reviewers for commenting on various drafts of the manuscript. Advice provided by L. G Harris in early stages of this project was particularly helpful. We also thank J. Taylor for statistical advice.

\section{LITERATURE CITED}

Arrontes, J. (1990). Composition, distribution on host and seasonality of epiphytes on three intertidal algae. Botanica mar 33: 205-211

Ballantine, D. L. (1979). The distribution of algal epiphytes on macrophyte hosts offshore from La Parguera, Puerto Rico, Botanica mar 22: 107-111

Benzing, D. H. (1987). Vascular epiphytism: taxonomic participation and adaptive diversity. Ann. Missouri Bot. Gard. 74: 183-204

Bidwell, R. G. S. (1958). Photosynthesis and metabolism of marine algae II. A survey of rates and products of photosynthesis in $\mathrm{C}_{14} \mathrm{O}_{2}$. Can. J. Bot. 36: 337-349

Brawley, S. H., Adey, W. H. (1981). The effect of micrograzers on algal community structure in a coral reef microcosm. Mar Biol. 61. 167-177

Burke, J. M. (1986). Studies on the relationship between the obligate epiphyte Polysiphonia lanosa (Rhodophyta) and its host Ascophyllum nodosum (Phaeophyta). Honours thesis (Bachelor), St. Xavier Univ., Anntogonish, Nova Scotia

Buschmann, A., Santelices, B. (1987). Micrograzers and spore release in Iridaea laminarioides Bory (Rhodophyta: Gigartinales). J. exp. mar. Biol. Ecol. 108: 171-179

Cousens, R. (1985). Frond size distributions and the effects of the algal canopy on the behaviour of Ascophyllum nodosum (L.) Le Jolis. J. exp. mar. Biol. Ecol. 92: 231-249

Cousens, R. (1986). Quantitative reproduction and reproductive effort by stands of the brown alga Ascophyllum nodosum (L.) Le Jolis in south-eastern Canada. Estuar. coast. Sci. 22: 495-50?

D'Antonio, C. (1985). Epiphytes on the rocky intertidal algal, Rhodomela larix (Turner) C. Agardh: negative effects on the host and food for herbivores? J. exp. mar. Biol. Ecol. 86: $197-218$

den Hartog, C. (1972). Substratum: Multicellular plants. In: Kinne, O. (ed.) Marine ecology, Vol. I, Environmental factors, Part 3. Wiley, New York, p. 1277-1289

Doherty, P. J. (1981). Coral reef fishes: recruitment limited assemblages? Proc. Fourth Int. Coral Reef Symp. (Manilla) 2: $465-470$

Doherty, P. J., Williams, D. McB. (1988). The replenishment of coral reef fish populations. Oceangr. mar Biol. A. Rev. 26: $487-551$

Ducker, S. C., Knox, R. B. (1984). Epiphytism at the cellular level with special reference to algal epiphytes. In: Linskens, H. F., Heslop-Harrison, J. (eds.) Encyclopedia of plant physiology. New series, Springer-Verlag, Berlin, Vol. 17, p. $113-133$

Duffy, J. E. (1990). Amphipods on seaweeds: partners or pests? Oecologia 83: 267-276

Filion-Myklebust, C., Norton, T (1981). Epidermis shedding in the brown seaweed Ascophyllum nodosum (L.) Le Jolis, and its ecological significance. Mar. Biol. Lett. 2: 45-51

Fralick, R. A., Mathieson, A. C. (1975). Physiological ecology of Polysiphonia species. Mar. Biol. 29: 29-36

Forrester, G. E. (1990). Factors influencing the juvenile demography of a coral reef fish. Ecology 71: 1666-1681

Garbary, D. J., Gautam, A. (1989). The Ascophyllum, Polysiphonia, Mycosphaerella symbiosis I. Population ecology of Mycosphaerella from Nova Scotia. Botanica mar. 32 $181-186$

Gonzalez, M. A., Goff, L. J. (1989). The red algal epiphytes Microcladia coulteri and $M$. californica (Rhodophyceae, Ceramiaceae). II. Basiphyte specificity. J. Phycol. 25 $558-567$

Grahame, J., Hanna, F. S. (1989). Factors affecting the dis- 
tribution of the epiphytic fauna of Corallina officinalis (L.) on an exposed rocky shore. Ophelia 30: 113-129

Harlin, M. M. (1987). Allelochemistry in marine macroalgae. CRC crit. Rev. Pl. Sci. 5: 237-249

Harlin, M. M., Craigie, J. S. (1975). The distribution of photosynthate in Ascophyllum nodosum as it relates to epiphytic Polysiphonia lanosa. J. Phycol. 11. 109-113

Hay, M. E. (1981a). Herbivory, algal distribution, and the maintenance of between-habitat diversity on a tropical fringing reef. Am. Nat. 118: 520-540

Hay, M. E. (1981b). The functional morphology of turf-forming seaweeds: persistence in stressful marine habitats. Ecology 62: 739-750

Hay, M. E. (1986). Associational plant defenses and the maintenance of species diversity: turning competitors into accomplices. Am. Nat. 128: 617-648

Hayward, P. J. (1980). Invertebrate epiphytes of coastal marine algae. In: Price, J. H., Irvine, D. E. G., Farnham, W. F. (eds.) The shore environment, Vol. 2; Ecosystems. Academic Press, London, New York, p. 761-787

Johansen, H. W. (1981). Coralline algae, a first synthesis, CRC Press, Boca Raton, Florida

Kohlmeyer, J., Kohlmeyer, E. (1972). Is Ascophyllum nodosum lichenized? Botanica mar. 15: 109-112

Lewis, J. R. (1964). The ecology of rocky shores. English Universities Press, London

Lobban, C. S., Baxter, D. M. (1983). Distribution of the red algal epiphyte Polysiphonia lanosa on its brown algal host Ascophyllum nodosum in the Bay of Fundy, Canada. Botanica mar 26: 533-538

Lubchenco, J. (1978). Plant species diversity in a marine intertidal community: importance of herbivore food preference and algal competitive abilities. Am. Nat. 112: 23-39

Lubchenco, J (1980). Algal zonation in the New England rocky intertidal community: an experimental analysis. Ecology 61: 333-344

Lubchenco, J., Gaines, S. D. (1981). A unified approach to marine plant-herbivore interactions. I. Populations and communites. A. Rev. Ecol. Syst. 405-437

Markham, J. W (1969). Vertical distribution of epiphytes on the stipe of Nereocystis luetkeana (Mertens) Postels and Ruprecht. Syesis 2: 227-239

Mathieson, A. C. (1989). Phenological patterns of Northern New England seaweeds. Botanica mar 419-438

Mathieson, A. C., Hehre, E. J. (1986). A synopsis of New Hampshire seaweeds. Rhodora 88: 1-139

Mathieson, A. C., Hehre, E. J., Reynolds, N. B. (1981). Investigations of New England marine algae I.: a floristic and descriptive ecological study of the marine algae at Jaffery Point, New Hampshire, USA, Botanica mar. 24: 521-532

Mathieson, A. C., Penniman, C. A. (1986). A phytogeographic interpretation of the marine flora from the Isle of Shoals. USA Botanica mar 29:413-434

Mathieson, A. C., Penniman, C. A., Harris, L. G. (1991). Northwest Atlantic rocky shore ecology. In: Mathieson, A. C., Nienhuis, P. (eds.) Ecosystems of the world, Vol. 24, Intertidal and littoral ecosystems. Elsevier Scientifıc PubLishers, Amsterdam, p. 109-191

Mathieson, A. C., Shipman, J. W., O'Shea, J. R., Hasevlat, R. C. (1976). Seasonal growth and reproduction of estuarine fucoid algae in New England. J. exp. mar. Biol. Ecol. 25: 273-284

This article was presented by M. Hay, Morehead City, North Carolina, USA
McBane, C. D. Croker, R. A. (1983). Animal-algal relationships of the amphipod Hyale nilssoni (Rathke) in the rocky intertidal. J. Crustacean Biol. 3: 592-601

Moss, B. L. (1982). The control of epiphytes by Halidrys siliquosa. Phycologia 21: 185-191

Norton, T A., Benson, M. R. (1983). Ecological interactions between the brown seaweed Sargassum muticum and its associated fauna. Mar Biol. 75: 169-177

Orth, R. J., Montfrans, J. V. (1984). Epiphyte-seagrass relationships with an emphasis on the role of micrograzing Aquat. Bot. 18: 43-69

Pearson, C. A., Evans, L. V (1989). Polysiphonia lanosabasiphyte inter-relationships. Br. phycol. J. 24: 310-311

Pearson, C. A., Evans, L. V (1990). Settlement and survival of Polysiphonia lanosa (Ceramiales) spores on Ascophyllum nodosum and Fucus vesiculosus (Fucales). J. Phycol. 26: 597-603

Rawlence, D. J., Taylor, A. R. A. (1970). The rhizoids of Polysiphonia lanosa. Can. J. Bot. 48: 607-611

Rodriguez, C. and Stoner, A. W (1990\}. The epiphytic community of mangrove roots in a tropical estuary: distribution and biomass. Aquat. Bot. 36: 117-126

Russell, G. (1988). Distribution and development of some Manx epiphyte populations. Helgoländer Meeresunters. 42: $477-492$

Russell, G., Veltcamp, C. J. (1984). Epiphyte survival on skinshedding macrophytes. Mar. Ecol. Prog. Ser 18: 149-153

Sideman, E. J., Mathieson, A. C. (1983). Ecological and genecological distinctions of a high intertidal dwarf form of Fucus distichus (L.) Powell. J. exp. mar. Biol. Ecol. 72 : $171-188$

Steneck, R. S. (1982). Adaptive trends in the ecology and evolution of crustose coralline algae (Rhodophyta, CoralLinaceae). Ph.D. dissertation, John Hopkins University, Baltimore, Maryland

Taylor, W R. (1957). Marine algae of the Northeastern Coast of North America. University of Michigan Press, Ann Arbor

Turner, H. G. H., Evans, L. V (1977). Physiological studies on the relationship between Ascophyllum nodosum and Polysiphonia lanosa. New Phytol. 79: 363-371

Underwood, A. J. (1981). Techniques of analysis in experimental marine biology. Oceanogr. mar. Biol. A. Rev. 19 513-605

Underwood, A. J., Denley, E. J. (1984). Paradigms, explanations and generalizations in models for the structure of intertidal communities of rocky shores. In: Strong, D. R., Simberloff, D., Abele, L. G., Thistle, A. B. (eds.) Ecological communites: conceptual issues and the evidence. Princeton University Press, Princeton, p. 151-180

Victor, B. C. (1983). Recruitment and population dynamics of a coral reef fish. Science 219: 419-420

Whittick, A. (1983) Spatial and temporal distributions of dominant epiphytes on the stipes of Laminaria hyperborea (Gunn.) Fosl. (Phaeophyta: Laminariales) in S. E. Scotland. J. exp mar. Biol. Ecol. 73: 1-10

Zapata, O., McMillan, C. (1979). Phenolıc acids in seagrasses. Aquat. Bot. 7: 307-317

Zar, J, H. (1984). Biostatistical analysis. Prentice-Hall, Englewood Cliffs, New Jersey

Zimmermann, R., Gibson, R., Harnngton, J. (1979). Herbivory and detritivory among gammaridean amphipods from a Florida seagrass community. Mar. Biol. 54: 41-47

Manuscript first received: March 6, 1991

Revised version accepted: August 28, 1991 